\title{
Path Analysis on the Determinants of Pap Smear Uptake in Women of Reproductive Age in Tegal, Central Java
}

\author{
Riska Armadhani'1), Ambar Mudigdo²), Uki Retno Budihastuti3) \\ 1)Masters Program in Public Health, Universitas Sebelas Maret \\ ${ }^{2)}$ Department of Anatomic, Faculty of Medicine, Universitas Sebelas Maret \\ 3)Department of Obstetrics and Gynecology, Dr. Moewardi Hospital, Surakarta
}

\begin{abstract}
Background: Cervical cancer is a leading cause of cancer-related deaths in women in developing countries. Although Pap smear is known as an effective strategy to reduce the burden of cervical cancer, it is underused in developing countries at around $19 \%$. This study aimed to examine the determinants of Pap smear uptake in women of reproductive age using Health Belief Model (HBM).

Subjects and Method: This was a case control study conducted in Tegal, Central Java, from October 4 to November 2, 2018. A sample of 200 women of reproductive age was selected by fixed disease sampling. The dependent variable was Pap smear uptake. The independent variables were perceived benefit, susceptibility, seriousness, and threat, cues to action, education, knowledge, and peer support. The data were collected by questionnaire and analyzed by path analysis run on Stata 13.

Results: Pap smear uptake directly increased with stronger perceived threat $(b=1.18 ; 95 \% \mathrm{CI}=$ 0.44 to $1.92 ; \mathrm{p}=0.002)$, stronger perceived benefit $(\mathrm{b}=1.40 ; 95 \% \mathrm{CI}=0.63$ to $2.16 ; \mathrm{p}<0.001)$, and higher self-efficacy ( $b=1.48 ; 95 \% \mathrm{CI}=0.73$ to $2.24 ; \mathrm{p}<0.001)$. Pap smear uptake was indirectly affected by perceived susceptibility, perceived seriousness, cues to action, education, knowledge, and peer support.

Conclusion: Pap smear uptake is directly affected by perceived threat, perceived benefit, and selfefficacy. It is indirectly affected by perceived susceptibility, perceived seriousness, cues to action, education, knowledge, and peer support.
\end{abstract}

Keywords: Pap smear, Health Belief Model, path analysis

\section{Correspondence:}

Riska Armadhani. Masters Program in Public Health, Universitas Sebelas Maret, Jl. Ir. Sutami 36 A, Surakarta 57126, Central Java. Email: riska.armadhani@gmail.com

\section{BACKGROUND}

Cervical cancer is the leading cause of cancer-related deaths in women in developing countries. In 2012, no fewer than 445,000 new cases of cervical cancer were recorded and 270,000 deaths were reported (WHO, 2015).

In 2013, the prevalence of cervical cancer patients in Indonesia was $0.8 \%$, with 98,692 cases. While in Central Java, the prevalence of cervical cancer cases was reported at $1.2 \%$ with an estimated total of 19,734 cases (KPKN, 2017). Based on data from the Tegal City Health Office in 2016, there were 129 reported cervical cancer cases, 3 of them died.

Although screening is generally known as an effective strategy to reduce the burden of cervical cancer, its use specifically in several developing countries is still very concerning (Idowu et al., 2016). Cancer screening programs in some countries with lower middle income, the average coverage is only 19\% (Ndejjo et al., 2016). The coverage of cervical cancer screening in 
Indonesia is still very low at $5 \%$ of the target of 80\% (Samadi, 2011).

The low visitation of cervical cancer screening is related to several factors including knowledge of cervical cancer and cancer screening, distance to the place of service, attitudes toward cervical cancer screening (feeling uncomfortable when undergoing screening and fear of screening results) (Farooqui et al., 2013; Jia et al., 2013; Ma et al., 2013).

Based on the theory of HBM behavior, the researchers were interested in examining the determinants of using a Pap smear in women of childbearing age in Tegal. The renewal of this research is by using path analysis that has never been done in previous studies.

\section{SUBJECTS AND METHOD}

\section{Study Design}

This was an analytic observational study with a case control design. The study was conducted in Tegal, Central Java, from October 4 to November 2, 2018.

\section{Population and sample}

The population in this study was all women aged 30-50 years in the Tegal. A sample of 200 women was selected for this study by fixed disease sampling consisted of $5^{0}$ women who had carried out a Pap smear in 2017 and 150 women who did not take Pap smear.

\section{Study variables}

The dependent variable was Pap smear uptake. The independent variables were the perceived benefit, susceptibility, threat, and seriousness, self-efficacy, cues to action, education, knowledge, and peer support.

\section{Operational definition of variables}

Pap smear uptake was defined as an action taken to determine the presence of cancer cell in the cervix using the Pap smear method, at least once a three year period.
The measurement scale was categorical, coded $\mathrm{o}$ for no and 1 for yes.

Perceived benefit was defined as a woman's view of the benefits of conducting a Pap smear. The measurement scale was continuous and transformed into dichotomous, $o$ for weak and 1 for strong.

Perceived susceptibility was defined as the view of a woman about the possibility of infected with cervical cancer. The measurement scale was continuous and transformed into dichotomous, $\mathrm{o}$ for weak and 1 for strong.

Perceived threat was defined as a woman's view of cervical cancer that can threaten her or not feel threatened because she feels healthy. The measurement scale was continuous and transformed into dichotomous, o for weak and 1 for strong.

Perceived seriousness was defined as a woman's view of the possible severity of cervical cancer. The measurement scale was continuous and transformed into dichotomous, $\mathrm{o}$ for weak and 1 for strong.

Self-efficacy was defined as a belief in one's own ability to carry out cervical cancer prevention behaviors using a Pap smear. The measurement scale was continuous and transformed into dichotomous, o for weak and 1 for strong.

Cues to action was defined as a trigger factor that moves a woman to accept the behavior of using a Pap smear as a preventive measure for cervical cancer. The measurement scale was continuous and transformed into dichotomous, $\mathrm{o}$ for weak and 1 for strong.

Education was defined as last education of the respondents obtained through formal education. The measurement scale was categorical, coded o for $<$ Senor high school and 1 for $\geq$ Senior high school.

Peer support mean giving assistance done by the respondent's peers to do Pap Smear tests in the form of verbal and non 
verbal. The measurement scale was continuous and transformed into dichotomous, $\mathrm{o}$ for weak and 1 for strong.

Knowledge was defined as the study subject's ability to understand and explain understanding, symptoms, risk factors, prevention and treatment of cervical cancer, and early detection of cervical cancer using the Pap smear method. The measurement scale was continuous and transformed into dichotomous, o for low and 1 for high.

\section{Data Analysis}

Data analysis techniques used were univariate, bivariate, and multivariate analysis. Univariate analysis aims to explain each characteristic data. Bivariate analysis aims to analyze the relationship between two variables with the Chi square test. Multivariate analysis used path analysis to determine the direct and indirect effects of the relationships between study variables. Path analysis steps included model specification, model identification, model fit, parameter estimate, and model respecification.

\section{Ethical Clearance}

The ethical clearance of this study include the informed consent, anonymity, confidentiality and ethical agreements that have been obtained from the commission of health research ethics at the Faculty of Medicine, SebelasMaret University with Number 203 / UN27 .6 / KEPK / 2018.

\section{RESULTS}

1. Univariate Analysis

Table 1 shows that women with strong perceptions of benefits amounting to 91 (45.5\%) and those who were weak amounting to 109 (54.5\%). Women with a strong perception of vulnerability were $87(43.5 \%)$ and weak amounting to 113 (56.5\%). Women with perceptions of strong threats were 88 (44\%) and weak of $112(56 \%)$.
Table 1. Univariat Analysis

\begin{tabular}{|c|c|c|}
\hline Variable & $\mathbf{n}$ & \% \\
\hline \multicolumn{3}{|l|}{ Pap smear status } \\
\hline Screening & 50 & 25 \\
\hline Never & 150 & 75 \\
\hline \multicolumn{3}{|l|}{ Perceived benefit } \\
\hline Strong & 91 & $45 \cdot 5$ \\
\hline Weak & 109 & $54 \cdot 5$ \\
\hline \multicolumn{3}{|c|}{ Perceived susceptibility } \\
\hline Strong & 87 & $43 \cdot 5$ \\
\hline Weak & 113 & 56.5 \\
\hline \multicolumn{3}{|l|}{ Perceived threat } \\
\hline Strong & 88 & 44 \\
\hline Weak & 112 & 56 \\
\hline \multicolumn{3}{|c|}{ Perceived seriousness } \\
\hline Strong & 86 & 43 \\
\hline Weak & 114 & 57 \\
\hline \multicolumn{3}{|l|}{ Cues to action } \\
\hline Strong & 77 & 38.5 \\
\hline Weak & 123 & 61.5 \\
\hline \multicolumn{3}{|l|}{ Self-Efficacy } \\
\hline Strong & 79 & 39.5 \\
\hline Weak & 121 & 60.5 \\
\hline \multicolumn{3}{|l|}{ Peer support } \\
\hline High & 81 & 40.5 \\
\hline Low & 119 & $59 \cdot 5$ \\
\hline \multicolumn{3}{|l|}{ Knowledge } \\
\hline High & 86 & 43 \\
\hline Low & 114 & 57 \\
\hline \multicolumn{3}{|l|}{ Education level } \\
\hline$\geq$ Senior high school & 150 & 75 \\
\hline$<$ Senior high school & 50 & 25 \\
\hline
\end{tabular}

Women with strong perceptions of seriousness were 86 (43\%) and weak amounting to 114 (57\%). Women with a signal to act strongly were 77 (38.5\%) and weak amounting to 123 (61.5\%). Women with strong self-efficacy were 79 (39.5\%) and weak amounting to 121 (60.5\%).

Women with high-level support of 81 (40.5\%) and low amounting to 119 (59.5\%). Women with a high level of knowledge were 86 (43\%) and low amounting to 114 (57\%). Women with a high level of education were 150 (75\%) and low amounting to 50 (25\%).

\section{Bivariate Analysis}

Table 2 shows the relationship of perceived benefit, perceived susceptibility, perceived 
threat, perceived seriousness, self-efficacy, peer support on Pap smear uptake. cues to action, education, knowledge, and

Table 2. The results of bivariate analysis

\begin{tabular}{|c|c|c|c|c|c|c|c|}
\hline \multirow{3}{*}{$\begin{array}{l}\text { Independent } \\
\text { variables }\end{array}$} & \multicolumn{4}{|c|}{ Pap smear uptake } & \multirow{3}{*}{$\mathbf{O R}$} & \multirow{3}{*}{$95 \% \mathrm{CI}$} & \multirow{3}{*}{$\mathbf{p}$} \\
\hline & \multicolumn{2}{|c|}{ No } & \multicolumn{2}{|c|}{ Yes } & & & \\
\hline & $\mathbf{n}=\mathbf{1 5 0}$ & $\%$ & $\mathbf{n}=\mathbf{5 0}$ & $\%$ & & & \\
\hline \multicolumn{8}{|l|}{ Perceived Benefit } \\
\hline Strong & 56 & $37 \cdot 3$ & 15 & 30 & \multirow{3}{*}{3.91} & \multirow{3}{*}{1.96 to 7.80} & \multirow{3}{*}{$<0.001$} \\
\hline Weak & 94 & 62.7 & 35 & 70 & & & \\
\hline Perceived Suscepti & & & & & & & \\
\hline Strong & 53 & $35 \cdot 3$ & 34 & 68 & \multirow{3}{*}{3.88} & \multirow{3}{*}{1.96 to 7.69} & \multirow{2}{*}{$<0.001$} \\
\hline Weak & 97 & 64.7 & 16 & 32 & & & \\
\hline \multicolumn{6}{|l|}{ Perceived Threat } & & \\
\hline Strong & 54 & 36 & 34 & 68 & \multirow{3}{*}{3.77} & \multirow{3}{*}{1.91 to 7.46} & \multirow{3}{*}{$<0.001$} \\
\hline Weak & 96 & 64 & 16 & 32 & & & \\
\hline Perceived Seriousi & & & & & & & \\
\hline Strong & 55 & 36.7 & 31 & 62 & \multirow{3}{*}{2.81} & \multirow{3}{*}{1.45 to 5.45} & \multirow{3}{*}{0.002} \\
\hline Weak & 95 & $63 \cdot 3$ & 19 & 38 & & & \\
\hline Cues to Action & & & & & & & \\
\hline Strong & 48 & 32 & 29 & 58 & \multirow{3}{*}{2.93} & \multirow{3}{*}{1.52 to 5.66} & \multirow{3}{*}{0.001} \\
\hline Weak & 102 & 68 & 21 & 42 & & & \\
\hline Self-Efficacy & & & & & & & \\
\hline Strong & 48 & 32 & 31 & 62 & \multirow{3}{*}{3.46} & \multirow{3}{*}{1.78 to 6.75} & \multirow{3}{*}{$<0.001$} \\
\hline Weak & 102 & 68 & 19 & 38 & & & \\
\hline Peer Support & & & & & & & \\
\hline High & 49 & 32.7 & 32 & 64 & \multirow{3}{*}{3.66} & \multirow{3}{*}{1.87 to 7.16} & \multirow{3}{*}{$<0.001$} \\
\hline Low & 101 & $67 \cdot 3$ & 18 & 36 & & & \\
\hline Knowledge Level & & & & & & & \\
\hline High & 53 & $35 \cdot 3$ & 33 & 66 & & & \\
\hline Low & 97 & 64.7 & 17 & 34 & 3.55 & 1.81 to 6.97 & $<0.001$ \\
\hline Educational Level & & & & & & & \\
\hline High & 108 & 72 & 42 & 84 & & & \\
\hline Low & 42 & 28 & 8 & 16 & 2.04 & 0.88 to 4.71 & 0.090 \\
\hline
\end{tabular}

\section{Path Analysis}

Table 3 shows that there was a positive relationship between perceived threat and Pap smear uptake and it was statistically significant $(b=1.18 ; 95 \% \mathrm{CI}=0.44$ to 1.92 ; $\mathrm{p}=0.002$ ). Women with strong perceived threat more likely to use Pap smear than women with weak perceived threat.

There was a relationship between perceived benefit and Pap smear uptake and it was statistically significant $(b=1.40$; 95\% CI $=0.63$ to $2.16 ; \mathrm{p}<0.001)$. Women with strong perceived benefit more likely to use Pap smear than women with weak perceived benefit.

There was a relationship between selfefficacy and Pap smear uptake $(b=1.48$; $95 \% \mathrm{CI}=0.73$ to $2.24 ; \mathrm{p}<0.001)$. Women with strong self-efficacy more likely to use Pap smear than women with weak selfefficacy.

There was a relationship between perceived susceptibility and perceived threat $(\mathrm{b}=0.55 ; 95 \% \mathrm{CI}=-0.03$ to $1.14 ; \mathrm{p}=$ o.067). Women with a strong perceived susceptibility more likely to had perceived 
threat, eventually increased Pap smear uptake.

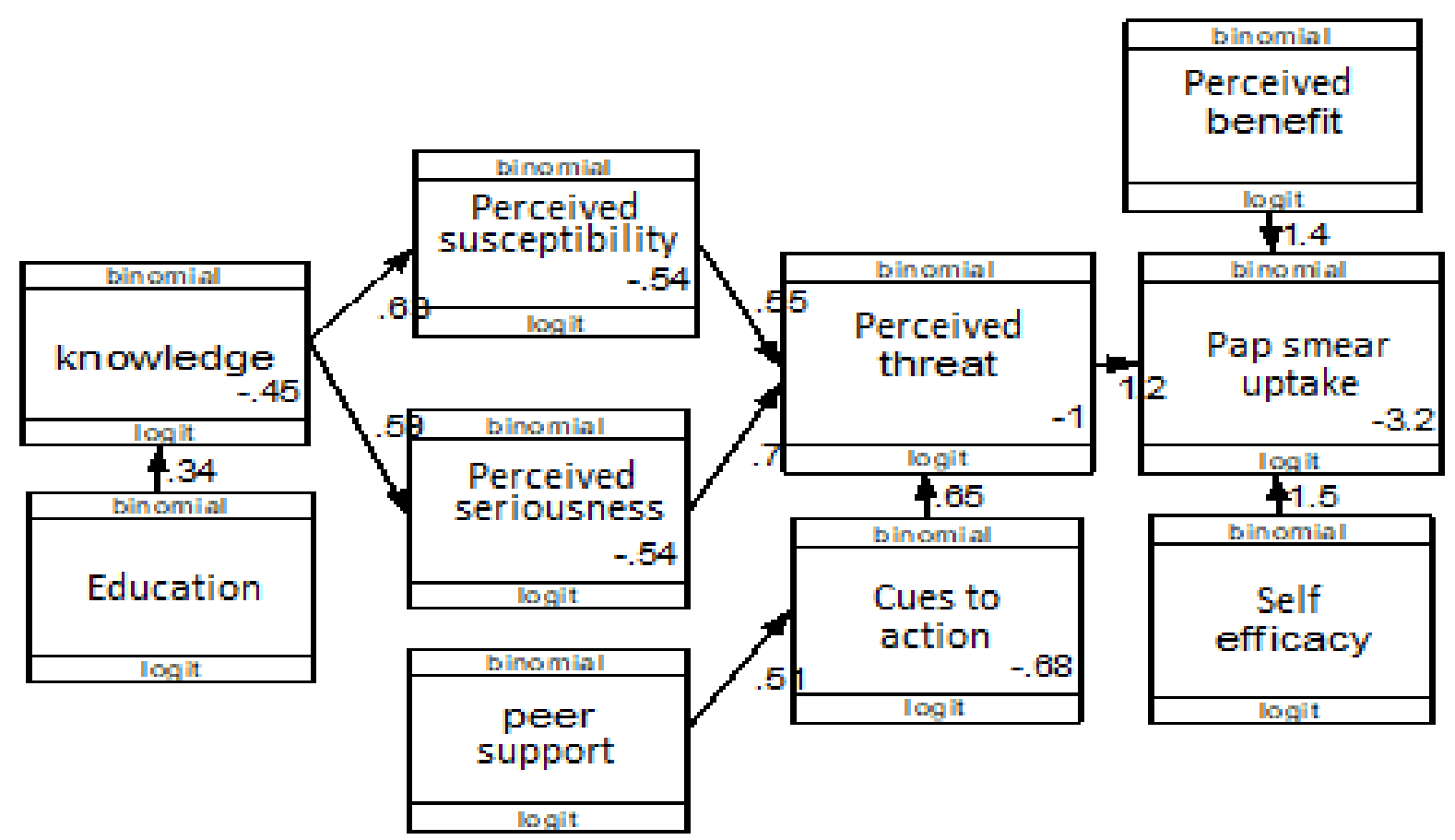

Figure 1. Path model with estimation

There was a relationship between perceived seriousness and perceived threat $(\mathrm{b}=$ $0.69 ; 95 \% \mathrm{CI}=0.10$ to $1.28 ; \mathrm{p}=0.021$ ). Women with strong perceived seriousness were more likely to have strong perceived threat which can increase Pap Smear uptake compared to women who have weak perceived seriousness.

There was a relationship between cues to action and perceived threat $(\mathrm{b}=0.64$; $95 \% \mathrm{CI}=0.04$ to $1.24 ; \mathrm{p}=0.035$ ). Women with strong cues to action were more likely to have strong perceived threat which can increase Pap smear uptake compared to women who have weak cues to action.

There was a relationship between peer support and cues to action $(b=0.50 ; 95 \%$ $\mathrm{CI}=-0.07$ to $1.08 ; \mathrm{p}=0.086$ ). Women with strong peer support were more likely to have strong cues to action which can increase Pap smears uptake compared to women with weak peer support.
There was a relationship between knowledge level and perceived susceptibility $(\mathrm{b}=0.63 ; 95 \% \mathrm{CI}=0.06$ to $1.20 ; \mathrm{p}=$ o.029). Women with high knowledge were more likely to have strong perceived susceptibility which can increased Pap smears uptake compared to women with low knowledge.

There was a relationship between knowledge and perceived seriousness $(\mathrm{b}=$ $0.58 ; 95 \% \mathrm{CI}=0.01$ to $1.15 ; \mathrm{p}=0.044)$. Women with high knowledge were more likely to have strong perceived seriousness which can increase Pap smears uptake compared to women with low knowledge.

There was a relationship between educational and perceived seriousness $(\mathrm{b}=$ $0.74 ; 95 \% \mathrm{CI}=0.05$ to $1.42 ; \mathrm{p}=0.034)$. Highly-educated women were more likely to have strong perceived seriousness which can increase Pap smear uptake compared to women with low knowledge. 
Table 3. The results of path analysis

\begin{tabular}{|c|c|c|c|c|c|c|}
\hline \multirow[b]{2}{*}{$\begin{array}{l}\text { Dependent } \\
\text { Variable }\end{array}$} & & \multirow[b]{2}{*}{ Independent Variable } & \multirow[b]{2}{*}{ b } & \multicolumn{2}{|c|}{$95 \%$ CI } & \multirow[b]{2}{*}{$\mathbf{p}$} \\
\hline & & & & $\begin{array}{c}\text { Lower } \\
\text { Limit }\end{array}$ & $\begin{array}{l}\text { Upper } \\
\text { Limit }\end{array}$ & \\
\hline \multicolumn{7}{|l|}{ Direct Effect } \\
\hline \multirow[t]{3}{*}{ Pap smear uptake } & $\leftarrow$ & Perceived threat & 1.18 & 0.44 & 1.92 & 0.002 \\
\hline & $\leftarrow$ & Perceived benefit & 1.40 & 0.63 & 2.16 & $<0.001$ \\
\hline & $\leftarrow$ & Self efficacy & 1.48 & 0.73 & 2.24 & $<0.001$ \\
\hline \multicolumn{7}{|l|}{ Indirect Effect } \\
\hline \multirow[t]{3}{*}{ Perceived threat } & $\leftarrow$ & Perceived susceptibility & 0.55 & -0.03 & 1.14 & 0.067 \\
\hline & $\leftarrow$ & Perceived seriousness & 0.69 & 0.10 & 1.28 & 0.021 \\
\hline & $\leftarrow$ & Cues to Action & 0.64 & 0.04 & 1.24 & 0.035 \\
\hline Cues to Action & $\leftarrow$ & Peer support & 0.50 & -0.07 & 1.08 & 0.086 \\
\hline $\begin{array}{l}\text { Perceived } \\
\text { susceptibility }\end{array}$ & $\leftarrow$ & Knowledge & 0.63 & 0.06 & 1.20 & 0.029 \\
\hline $\begin{array}{l}\text { Perceived } \\
\text { seriousness }\end{array}$ & $\leftarrow$ & Knowledge & 0.58 & 0.01 & 1.15 & 0.044 \\
\hline Knowledge & $\leftarrow$ & Education & 0.74 & 0.05 & 1.42 & 0.034 \\
\hline
\end{tabular}

\section{$\frac{\text { DISCUSSION }}{\text { 1. The effect of perceived benefit on }}$ Pap smear uptake}

The result of analysis showed that there was a relationship between perceived benefit and the use of pap smear check which was statistically significant, by knowing the benefits of a Pap smear, individuals would be more interested and more aware of the importance of the Pap smear uptake/check.

The result of this study was in line with a study done by Ndejjo et al. (2016) which stated that the more known the benefits of the early detection of cervical cancer checks, the stronger the willingness of women to conduct the test. A study done by Jia et al. (2013), Marlow et al. (2015) also mentioned thatwomen who did not conduct cervical cancer screening have several reasons including not knowing the benefits of cervical cancer screening. Sulaeman (2016) also stated thatsomeone tend to adopt healthy behavior when they believed that this behavior would reduce the risk of a disease.

\section{The effect of perceived suscepti- bility on Pap smear uptake}

The result of analysis showed that there was a relationship between perceived susceptibility and the use of pap smear check which was statistically significant, when women realized that they were susceptible to cervical cancer, they would conduct an effort to prevent the disease by doing Pap smear check.

The result of this study was in line with a study done by Bayu et al. (2016) which stated that there was a significant relationship between perceived susceptibility and early detection of cervical cancer. Glanz et al. (2015) stated that women were more likely tocomply with the recommendations for the use of early detection of cervical cancer if they felt vulnerable to cervical cancer.

According to Sulaeman (2016), perceived susceptibility encourage someone to adopt healthy behavior. The greater the perceived risk, the more likely it was to engage in behavior to reduce the risk. But unfortunately, someone who believed that they were at low risk of developing an illness was more likely to engage in 
unhealthy or risky behavior.

\section{The effect of perceived threat on Pap smear uptake}

The result of analysis showed that there was a relationship between perceived threat and the use of pap smear check which was statistically significant. The perception or presumption about the threat of cervical cancer made the individuals to take Pap smears check. This was because they did not want to have cervical cancer so they would try to prevent the occurrence of cervical cancer.

The result of this study was in line with a study by Ncube et al. (2015) which stated that there was a significant relationship between perceived threat and early detection of cervical cancer. Many women with strong perceived threat about cervical cancer can place early detection of cervical cancer as a necessity. Ma et al. (2013) stated that perceived threat has a strong effect on a disease, someone with high perceived threat of a disease tend to take preventive action.

Sulaeman (2016) stated thatthe threat of an illness was perceived differently by each individual. In cancer disease, some people were afraid of the disease, but there were also those who thought that the disease was not so severe, or that the individual felt he/she would not be infected by the disease because she/he has no history of cancer.

\section{The effect of perceived seriousness} on Pap smear uptake

The result of analysis showed that there was a relationship between perceived severity and the use of pap smear check which was statistically significant. The perception or assumption about the severity of cervical cancer made the individuals to conduct a Pap smear test. This was because they did not want to get serious illness so they would make efforts to prevent cervical cancer.
The result of this study was in line with a statement of Nwobodo and Ba-Break (2016) which stated that there was a relationship between perceived seriousness and early detection of cervical cancer. Individuals who felt serious health problems were more likely to engage in behavior to prevent health problems (or reduce the severity).

\section{The effect of cues to action on Pap smear uptake}

The result of analysis showed that there was a relationship between cues to action and the use of pap smear check which was statistically significant. The perception of cues to action on a Pap smear test made the women to be motivated to conduct the test. This was because the information through friends, health personnels, counseling, newspaper, and electronic media influenced the behavior of Pap smear checks.

The result of this study was in line with a study by Ma et al. (2013) that there was a significant relationship between cues to action and early detection of cervical cancer. Behavior was also affected by cues to action. Karimy et al. (2017) stated that cues to action were needed to support the involvement in promoting health behavior. Cues to action wereevents, people, or things that change a behavior.

\section{The effect of self-efficacy on Pap smear uptake}

The result of analysis showed that there was a relationship between self-efficacy and the use of pap smear which was statistically significant. Individuals who have high selfefficacy would assumed a disease prevention as something that must be done.

The result of this study was in line with astudy done by Sidabutar et al. (2017) and Ma et al. (2013) which stated that selfefficacy has a significant effect on the use of early detection of cervical cancer. Women who have high self-efficacy can plan 
themselves for early detection of cervical cancer. Whereas women who did not have self-efficacy would avoid early detection of cervical cancer which was actually very beneficial for their health.

\section{The effect of peer support on Pap smear uptake}

The result of analysis showed that there was a relationship between peer support and the use of pap smear check which was statistically significant. Friends in groups can provide support and motivation for early detection of cervical cancer. Such support can be in the form of information about the experience, knowledge, and benefits obtained.

The result of this study was in line with astudy done by Wakhidah et al. (2017) and Ma et al. (2013) which stated thatthere was a significant relationship between peer support and early detection of cervical cancer. The role of peers was as a part of a group for socializing and sharing experiences.

\section{The effect of knowledge on Pap smear uptake}

The result of analysis showed that there was a relationship between knowledge level and the use of pap smear check which was statistically significant.

The result of this study was in line with a study done by Asthana et al. (2014); Bayu et al. (2016) which stated that there was a relationship between knowledge and early detection of cervical cancer. $\mathrm{Ni}$ et al. (2016) in Ghana also conducted a study about factors that affectcervical cancer screening in women, and it was found that from 392 women aged 10-74 years old, $68.4 \%$ of women have not heard about cervical cancer. The majority of $97.7 \%$ have not heard about Pap smear, and only 3 of 392 women who have conducted Pap smear screening.

A study by Jia et al. (2013) in China also mentioned thatwomen who were willing to do cervical cancer screening have a high level of knowledge. While the study by Marlow et al. (2015) stated that women who have limited knowledge about cervical cancer would have an impact on low early detection. Therefore, it was necessary to conduct cervical cancer awareness campaigns and health education efforts by health personnels.

\section{The effect of educational on Pap smear uptake}

The result of analysis showed that there was a relationship between education and the use of pap smear which was statistically significant. The higher the level of education, the easier it was to accept new things and adjust to them.

The result of this study was in line with a study by Bayu et al. (2016); Kasting et al. (2017) which stated that educational level has a significant effect on the use of early detection of cervical cancer. A study done by Wardhani et al. (2015) stated that women with high education were 2.6 times more likely to conduct Pap smear test than low-educated women.

The conclusion of this study was that there was a positive relationship between perceived benefit, perceived susceptibility, perceived threat, perceived seriousness, self-efficacy, cues to action, education, knowledge, and peer support on the use of Pap smear.

\section{REFERENCES}

Asthana S, Bhambani S, Sodhani P, Gupta S, Satyanarayana L (2014). A comparative study of cervical cancer screening methods in a rural community setting of North India. Indian Journal of Cancer, 51(2), 124. https://doi.org/10.4103/0019-509X.138172.

Bayu H, Berhe Y, Mulat A, Alemu A (2016). Cervical cancer screening service 
uptake and associated factors among age eligible women in Mekelle zone, Northern Ethiopia, 2015: A community based study using health belief model. PLoS ONE, 11(3), 1-13. https://doi.org/10.1371/journal.pone.0149908.

Dinkes Kota Tegal (2017). Profil Kesehatan Kota Tegal Tahun 2016. Tegal: Dinas Kesehatan Kota Tegal.

Farooqui M, Hassali MA, Knight A, Shafie AA, Farooqui MA, Saleem F, Haq NU, Aljadhey H (2013). A Qualitative Exploration Of Malaysian Cancer Patients' Perceptions Of Cancer Screening. BMC public health, 13(1): 48. http://dx.doi.org/10.1186/1471-2458$13-48$.

Glanz K, Rimer BK, Viswanath K (2015). Health behavior and health education: theory, research, and practice. John Wiley \& Sons. http://riskybusiness.web.unc.edu/files/2015/o1/Heal th-Behavior-and-Health-Education.pdf.

Idowu A, Olowookere SA, Fagbemi AT, Ogunlaja OA (2016). Determinants of Cervical Cancer Screening Uptake among Women in Ilorin, North Central Nigeria: A Community-Based Study. Journal of Cancer Epidemiology. https://doi.org/10.1155/2016/6469240.

Jia Y, Li S, Yang R, Zhou H, Xiang Q, Hu T, Feng L (2013). Knowledge about Cervical Cancer and Barriers of Screening Program among Women in Wufeng County, a High-Incidence Region of Cervical Cancer in China. PLoS ONE, 8(7), 2-8. https://doi.org/10.1371/journal.pone.0067005.

Karimy M, Azarpira H, Araban M (2017). Using health belief model constructs to examine differences in adherence to pap test recommendations among
Iranian Women. Asian Pacific Journal of Cancer Prevention: APJCP, 18(5), 1389-1394. https://doi.org/10.22034/APJCP.2017.18.5.1389.

Kasting ML, Wilson S, Zollinger TW, Dixon BE, Stupiansky NW, Zimet GD (2017). Differences in cervical cancer screening knowledge, practices, and beliefs: An examination of survey responses. Preventive Medicine Reports: 169174. https://doi.org/10.1016/j.pmedr.2016.12.013

Komite Penanggulangan Kanker Nasional (2017). Kanker serviks: pedoman nasional pelayanan kedokteran. Jakarta: Kemenkes RI. http://kanker.kemkes.go.id/guidelines/PNPKServiks.pdf

Ma GX, Gao W, Fang CY, Tan Y, Feng Z, Ge S, Nguyen JA (2013). Health Beliefs Associated with Cervical Cancer Screening among Vietnamese Americans. Journal of Women's Health, 22(3): 276-288. https://doi.org/10.1089/jwh.2012.3587

Marlow L, Waller J, Wardle J (2015). Barriers to cervical cancer screening among ethnic minority women: a qualitative study. The Journal of Family Planning and Reproductive Health Care/Faculty of Family Planning \& Reproductive Health Care, Royal College of Obstetricians \& Gynaecologists, 41(4): 248-254. https://doi.org/10.1136/jfprhc-2014101082.

Ncube B, Bey A, Knight J, Bessler P, Jolly $P E$ (2015). Factors associated with the uptake of cervical cancer screening among women in Portland, Jamaica. North American Journal of Medical Sciences, 7(3), 104-113. https://doi.org/10.4103/1947-2714.153922.

Ndejjo R, Mukama T, Musabyimana A, Musoke D (2016). Uptake of cervical cancer screening and associated fac- 
tors among women in rural Uganda: A cross sectional study. PLoS ONE, 11(2): 1-13. https://doi.org/10.1371/journal.pone.0149696.

Ebu NI, Mupepi SC, Siakwa MP, Sampselle CM (2016). Knowledge, practice, and barriers toward cervical cancer screening in Elmina, Southern Ghana. Int J Womens Health. 24(7):31-9. doi: 10.2147/IJWH.S71797.

Nwobodo H, Ba-Break M (2016). Analysis of the determinants of low cervical cancer screening uptake among Nigerian women. Journal of Public Health in Africa, 6(2), 12-19. https://doi.org/10.4081/jphia.2015.484.

Samadi P (2011). Yes, i know everything about kanker serviks!. Jakarta: Tiga Kelana.

Sidabutar S, Martini S, Wahyuni CU (2017). Analysis of factors affecting women of childbearing age to screen using visual inspection with acetic acid. Osong Public Health and Research Perspectives, 8(1): 61-64. https://- doi.org/10.24171/j.phrp.2017.8.1.08. Sulaeman SE (2016). Pembelajaran model dan teori perilaku kesehatan, konsep dan aplikasi. Surakarta: UNS Press.

Wakhidah MS, Hastuti URB, Dewi YLR (2017). The influence of personal factor, husband's support, health workers and peers toward the use of IVA screening among women of reproductive age in the Regency of Karanganyar. Journal of Health Promotion and Behavior, 2(2), 126139.

Wardhani GK, Mudigdo A, Qadrijati I (2015). Path analysis on the determinants of Pap smear utilization for cervical cancer early detection in women of reproductive age. Journal of Health Promotion and Behavior. 2(4): 359-370.

WHO (2015). Human Papillomavirus (HPV) and cervical cancer fact sheet. Available from: http://www.who.int/mediacentre/factsheets/fs380/en/. 